\title{
PML is induced by oncogenic ras and promotes premature senescence
}

\author{
Gerardo Ferbeyre, ${ }^{1}$ Elisa de Stanchina, ${ }^{1}$ Emmanuelle Querido, ${ }^{1}$ Nicole Baptiste,${ }^{2}$ Carol Prives, ${ }^{2}$ \\ and Scott W. Lowe $\mathrm{e}^{1,3}$ \\ ${ }^{1}$ Cold Spring Harbor Laboratory, Cold Spring Harbor, New York 11724 USA; ${ }^{2}$ Department of Biological Sciences, \\ Columbia University, New York, New York 10027 USA
}

\begin{abstract}
Oncogenic ras provokes a senescent-like arrest in human diploid fibroblasts involving the $\mathbf{R b}$ and p53 tumor suppressor pathways. To further characterize this response, we compared gene expression patterns between ras-arrested and quiescent IMR90 fibroblasts. One of the genes up-regulated during ras-induced arrest was promyelocytic leukemia (PML) protein, a potential tumor suppressor that encodes a component of nuclear structures known as promyelocytic oncogenic domains (PODs). PML levels increased during both ras-induced arrest and replicative senescence, leading to a dramatic increase in the size and number of PODs. Forced PML expression was sufficient to promote premature senescence. Like oncogenic ras, $P M L$ increased the levels of p16, hypophosphorylated $\mathbf{R b}$, phosphoserine-15 p53, and expression of p53 transcriptional targets. The fraction of $\mathrm{Rb}$ and $\mathrm{p} 53$ that colocalized with PML markedly increased during ras-induced arrest, and expression of $P M L$ alone forced $\mathrm{p} 53$ to the PODs. E1A abolished PML-induced arrest and prevented PML induction and p53 phosphorylation in response to oncogenic ras. These results imply that PML acts with Rb and p53 to promote ras-induced senescence and provide new insights into PML regulation and activity.
\end{abstract}

[Key words: senescence; ras; PML; p53; retinoblastoma protein; p16]

Received June 8, 2000; revised version accepted June 28, 2000.

Normal cells possess natural defenses that minimize the deleterious consequences of mutations, and these safeguards are often disrupted during multistep carcinogenesis. One such safeguard involves antiproliferative responses to excessive mitogenic signaling or oncogenic stress. For example, forced expression of the $c-m y c$ oncogene drives proliferation and simultaneously increases cellular susceptibility to apoptosis (Evan et al. 1992). Although the decision to proliferate or die can be influenced by additional factors, mutations that disable apoptosis allow uncontrolled proliferation and cooperate with myc during tumor development (Sherr and Weber 2000). Similarly, oncogenic ras promotes uncontrolled mitogenesis but when expressed in primary cells, provokes a permanent cell cycle arrest with features of senescence (Serrano et al. 1997). As a result, ras-induced arrest suppresses oncogenic transformation (Serrano et al. 1997; Lin et al. 1998; Hahn et al. 1999|. Indeed, the necessity to override this arrest explains the cooperative interactions between ras and immortalizing mutations for transformation and may be important during tumor progression (Serrano et al. 1997; Hahn et al. 1999).

Senescence was originally defined by the observation that primary cells have a genetically determined limit to their proliferative capacity; after which they permanently arrest with characteristic features (Hayflick 1965;

${ }^{3}$ Corresponding author.

E-MAIL lowe@cshl.org; FAX (516) 367-8454. for review, see Campisi 1997). Owing to the "end-replication problem", telomeres shorten during each cell division unless telomerase is expressed, and it appears that some aspect of telomere malfunction induces the senescent cell-cycle arrest (reviewed by Artandi and DePinho 2000). Although oncogenic ras does not promote telomere shortening (Shelton et al. submitted), the characteristics of ras-arrested cells are similar to cells undergoing replicative senescence. For example, cells arrested by serial passaging or oncogenic ras accumulate a senescence-associated $\beta$-galactosidase (SA- $\beta$-gal) (Dimri et al. 1995; Serrano et al. 1997). Moreover, these cells display similar patterns of gene expression that are markedly distinct from quiescent cells (Shelton et al. 1999). DNA damaging agents and other mitogenic oncogenes can also induce a senescent-like phenotype (Linke et al. 1997; Lin et al. 1998; Zhu et al. 1998; Chang et al. 1999; Dimri et al. 2000), implying that the process of cellular senescence reflects a common arrest program that is activated by diverse stimuli.

The most compelling link between ras-induced senescence and tumor suppression is their mutual dependence on tumor suppressor genes. For example, oncogenic ras induces $\mathrm{p} 53, \mathrm{p} 15^{\mathrm{INK} 4 \mathrm{~b}}, \mathrm{p} 16^{\mathrm{INK} 4 \mathrm{a}}$, and $\mathrm{p} 19^{\mathrm{ARF}}$ and leads to hypophosphorylation of $\mathrm{Rb}$ in several normal rodent and human cell types (Serrano et al. 1997; Palmero et al. 1998; Malumbres et al. 2000). Inactivation of either p53, p19 $\mathrm{ARF}$, or the INK4a/ARF locus bypasses ras-induced arrest in murine fibroblasts (Kamijo et al. 1997; Serrano 
et al. 1997; Palmero et al. 1998), and overexpression of these proteins is sufficient to induce senescence in some settings (Sugrue et al. 1997; Uhrbom et al. 1997; McConnell et al. 1998; Stott et al. 1998; Vogt et al. 1998; Wang et al. 1998a; Dimri et al. 2000). Viral oncoproteins that target the p53 and $\mathrm{Rb}$ pathways circumvent rasinduced arrest and cooperate with ras in oncogenic transformation (Serrano et al. 1997; Hahn et al. 1999; Morales et al. 1999). However, since the p53 and Rb pathways can also promote reversible checkpoint arrests, it is not obvious how senescence is maintained.

The mechanistic differences in the control of cellular senescence between human and murine cells have important ramifications for multistep carcinogenesis in each species. For example, species-specific differences in the control of replicative senescence involve variations in telomere length and dynamics, and this accounts for the unique requirement for telomerase activation during the transformation of human cells (Hahn et al. 1999). In contrast, species-specific differences in the control of premature senescence are unrelated to telomere biology but involve the relative contribution of the p53 pathway to the process (Serrano et al. 1997). Although oncogenic ras activates the p53 and $\mathrm{Rb}$ pathways in cells from both species, disruption of the p53 pathway is sufficient to override ras-induced arrest only in murine cells (Serrano et al. 1997; Palmero et al. 1998). As a consequence, murine cells lacking p53 are transformed by oncogenic ras, whereas inactivation of p53 in human cells does not rescue ras-induced arrest (Serrano et al. 1997). The only known activities that circumvent ras-induced arrest in human cells are viral oncoproteins such as adenovirus E1A, SV40 T antigen, papillomavirus E6/E7, and herpes virus LMP1 (Serrano et al. 1997; Hahn et al. 1999; Morales et al. 1999; Yang et al. 2000). These proteins typically disable both the $\mathrm{p} 16 / \mathrm{Rb}$ and $\mathrm{p} 53$ growth arrest but may also have additional targets. Therefore, escape from ras-induced arrest in human cells requires the evasion of multiple tumor suppressor pathways, the nature of which remains to be fully elucidated.

In this study, we set out to gain insights into the control of ras-induced senescence in human cells. We hypothesized that the onset of senescence involves a gene expression program that, in response to an initiating stimulus, gives rise to the senescent phenotype. To investigate this program, we conducted a differential gene expression screen to identify genes that were specifically altered during ras-induced senescence but not in quiescent-like arrests. Using this approach, we identify PML as a component of the premature senescence program induced by oncogenic ras, and provide evidence that PML acts in senescence control, in part, by modulating the p53 and Rb tumor suppressor pathways.

\section{Results}

$P M L$ is induced during premature senescence

We screened a cDNA array to identify transcripts that were differentially expressed between ras-arrested and quiescent cells. Oncogenic ras was introduced into whole populations of IMR90 human diploid fibroblasts using retroviral-mediated gene transfer. Cells were recovered ten days post-infection, at which time they had arrested at subconfluent density and were highly positive for SA- $\beta$-gal activity ( $>95 \%$ positive). For comparison, a parallel culture of IMR90 cells was infected with a control "empty" vector, and the cells were grown to confluence where they arrested by contact. These cells were quiescent and not positive for SA- $\beta$-gal $(<10 \%)$. Importantly, both ras-expressing and quiescent cell populations displayed a similar reduction in ${ }^{3} \mathrm{H}$-thymidine incorporation relative to exponentially growing controls (data not shown). ${ }^{33}$ P-labeled cDNA probes derived from mRNA from ras-arrested and quiescent cells were used to hybridize to Genome Systems cDNA arrays containing $<18,000$ known genes and expressed sequence tags (ESTs). Approximately 150 genes displayed greater than fivefold changes in two separate experiments. A series of genes known to be altered during replicative senescence and ras-induced arrest were also identified on the arrays (see Materials and Methods), although many of the differentially expressed genes were ESTs of unknown function.

Several known genes not previously associated with cellular senescence were differentially expressed in rasarrested cells. One of the most interesting up-regulated genes was $P M L$ (7.5-fold increase) (Fig. 1A). PML is a RING finger protein that localizes to large nuclear structures called promyelocytic oncogenic domains (PODs), ND10, or PML nuclear bodies (for review, see Zhong et al. 2000). PML was initially identified in acute promyelocytic leukemia (APL), in which it forms a reciprocal translocation $\mathrm{t}(15 ; 17)$ with the RAR $\alpha$ gene (de The et al. 1991; Goddard et al. 1991; Kakizuka et al. 1991; Kastner et al. 1992). In APL cells, the PML-RAR $\alpha$ fusion protein disrupts the PODs, but addition of retinoic acid disables the fusion protein leading to reformation of the PODs and differentiation (Dyck et al. 1994; Weis et al. 1994). These studies imply that PML has tumor-suppressor activity, which is supported by the observation that mice lacking PML are tumor prone (Wang et al. 1998b). Although the biochemical action of PML is not known, it may function in transcription control by recruiting transcription factors to the PODs (LaMorte et al. 1998; Doucas et al. 1999).

To further characterize the effects of oncogenic ras on PML, Northern blots were performed using probes against PML or a series of other senescence-related genes identified on our arrays. ras-arrested cells displayed a dramatic induction in several PML isoforms, and in the senescence-related markers PAI-1, stromelysin, and IL$1 \beta$ (Fig. 1B). IMR90 cells that underwent replicative senescence by serial passaging also induced PML. Consistent with a previous report (Shelton et al., unpubl.), the levels of stromelysin and IL-1 $\beta$ induced by oncogenic ras were more pronounced than during replicative senescence (Fig. 1B), perhaps because Ras signaling directly activates these genes (Sistonen et al. 1989), or because the onset of senescence is more synchronous in ras-ex- 
A
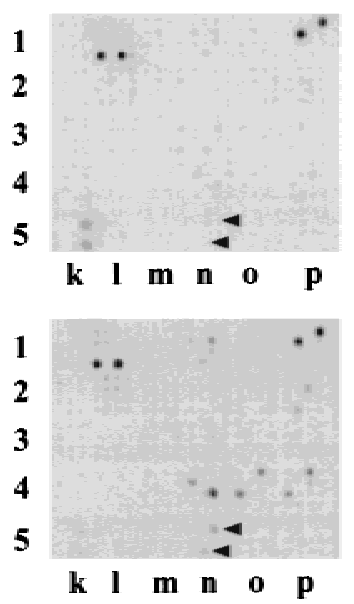

B

\section{R S ER}

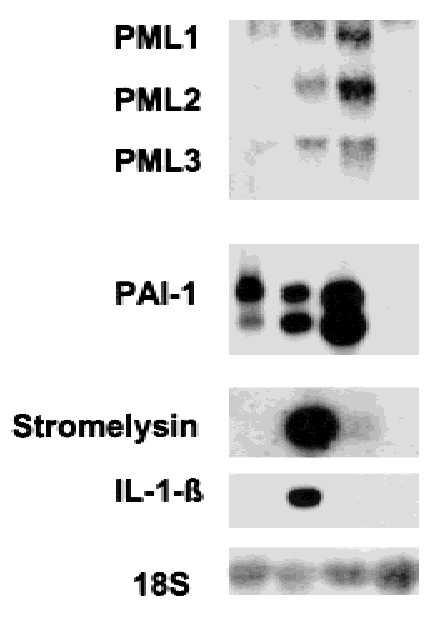

Figure 1. Oncogenic ras induces PML. $(A){ }^{33} \mathrm{P}$-labeled cDNA probes were generated from quiescent (top) and ras-arrested (bottom) IMR90 fibroblasts and used to hybridize to GDA arrays. The portion of each array that contains the $P M L$ cDNA (n-5, see arrows) is shown; each cDNA is arrayed in duplicate and in different orientations (see www.genomesystems.com). Note that the cDNAs located at p-1 and 1-1 are controls that show equal intensity between the filters, whereas several other cDNAs in this section displayed up- or down-regulation in rasarrested cells. $(B)$ Northern blot analysis of PML and the senescence-related genes PAI- 1 , stromelysin, and IL-1 $\beta$. IMR90 cells were infected with a control vector $(\mathrm{V})$, oncogenic ras $(\mathrm{R})$, or coinfected with E1A and oncogenic ras (ER). Alternatively, the cells were serially passaged until they had become senescent (S). Three major transcripts were visualized for PML (Goddard et al. 1991). The smaller of the two PAI-1 transcripts is the one whose up-regulation correlates better with senescence ( $\mathrm{Mu}$ and Higgins 1995).

pressing cells. In any case, E1A, which overrides rasinduced arrest, abolished the upregulation of PML and the other senescence-associated markers in response to oncogenic ras.

\section{PML oncogenic domains accumulate in response to oncogenic ras}

PML is the defining component of nuclear structures known as promyelocytic oncogenic domains (PODs). These structures also contain Sp100, a target of autoantibodies in primary billiary cirrhosis and also up-regulated in our arrays from ras-arrested cells (data not shown). To examine the impact of oncogenic ras on POD numbers and distribution, we examined the expression of PML and Sp100 by indirect immunofluorescence using specific antibodies. Oncogenic Ras induced the accumulation of nuclear bodies containing both PML and Sp100 and a similar increase was observed in senescent cells (Fig. 2A). To quantify this effect we conducted serial confocal microscopy on 100 randomly-chosen nuclei from control and ras-arrested cells (Fig. 2B). Cells arrested by oncogenic ras were positive for SA- $\beta$-gal and displayed a striking increase in the number, size, and intensity of the PODs relative to controls ( $37 \pm 13$ vs. $12 \pm 6$, respectively; see Fig. $2 \mathrm{~B}$ ). In contrast, cells arrested by serum-depletion, confluence, or forced p53 expression displayed low SA- $\beta$-gal activity and did not accumulate PODs (Fig. 2C). Consistent with the Northern analysis presented in Figure 1B, this increase in PODs in response to ras was not observed in cells expressing E1A (Fig. 2D).

Expression of oncogenic ras in IMR90 cells produces an initial mitogenic burst followed by the onset of cellular senescence (Lin et al. 1998). During this mitogenic period (e.g., 2 days postselection), ras-expressing cells were not positive for SA- $\beta$-gal and contained few PODs (Fig. 2E). However, PML bodies increased dramatically by day 4 and achieved a maximum at day 6 postinfection, co-incident with the time in which the cells underwent cell-cycle arrest and accumulated SA- $\beta$-gal (Fig. 2E). Thus, the accumulation of PODs in response to oncogenic ras is coincident with the onset of premature senescence and appears unique to the senescent state.

\section{PML induces premature senescence}

PML can inhibit cellular proliferation in a variety of tumor cell lines (for review, see Melnick and Licht 1999), but the consequences of stable PML expression in normal cells are poorly characterized. Therefore, we introduced $P M L$ into IMR90 and IMR90 (E1A) populations by retroviral-mediated gene transfer and measured BrdU incorporation to estimate DNA synthesis (Fig. 3B,C). By 10 days postinfection, forced $P M L$ expression in IMR90 cells produced a marked increase in POD numbers and intensity $(40 \pm 10$; Fig. $3 \mathrm{~A})$, as well as a fivefold reduction in the percentage of BrdU-positive cells, suggesting a potent growth arrest (Fig. 3B). E1A-expressing cells displayed a similar increase in POD numbers $(40 \pm 5)$ and PML levels (data not shown), although the intensity of PML staining in PODs was reduced (Fig. 3A). Moreover, in $\sim 25 \%$ of E1A-expressing cells, a substantial portion of the PML was localized to cytoplasmic conglomerates (Fig. 3A, arrow). The percentage of BrdU-positive cells coexpressing PML and E1A was similar to that observed in cells expressing E1A alone (Fig. 3B,C), implying that E1A completely abolished $P M L$-induced arrest. Neither a PML mutant lacking the nuclear localization signal (PMLnls-) or the proline rich RING finger B-box-1 (PMLprb-) were able to promote cell cycle arrest in a ${ }^{3} \mathrm{H}$-thymidine incorporation assay (Fig. 3D). Although these PML mutants were efficiently expressed, they were unable to induce formation of PODs (data not shown).

To further characterize PML-induced arrest, we used a growth assay that measures cell accumulation with time and examined the cell-cycle distribution of arrested cells following BrdU incorporation and flow cytometry. As expected, cells expressing oncogenic ras arrested after an initial period of growth (Fig. 4A, circles). In contrast, $P M L$-expressing cells grew slowly from the beginning 
Ferbeyre et al.

A
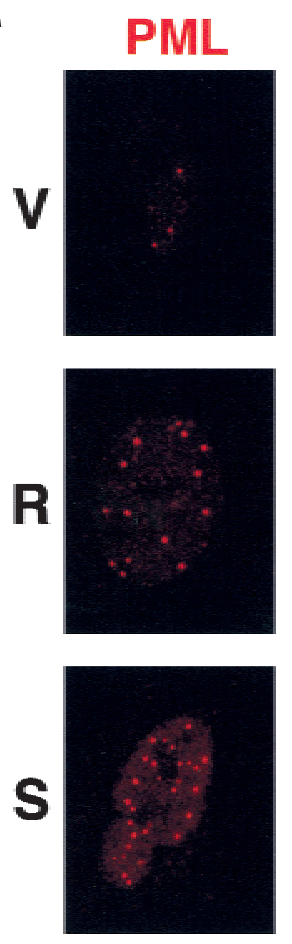

c

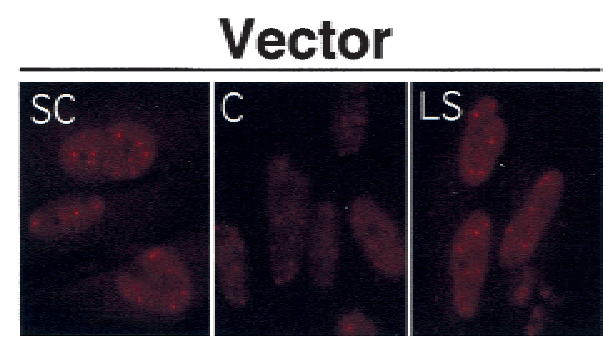

SA- $\beta$-gal $(5 \pm 2) \quad(7 \pm 4)$

D
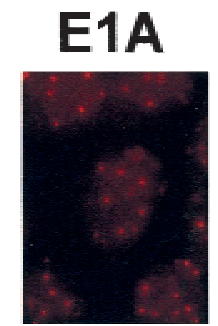

SA- $\beta-$ gal $(6 \pm 3)$
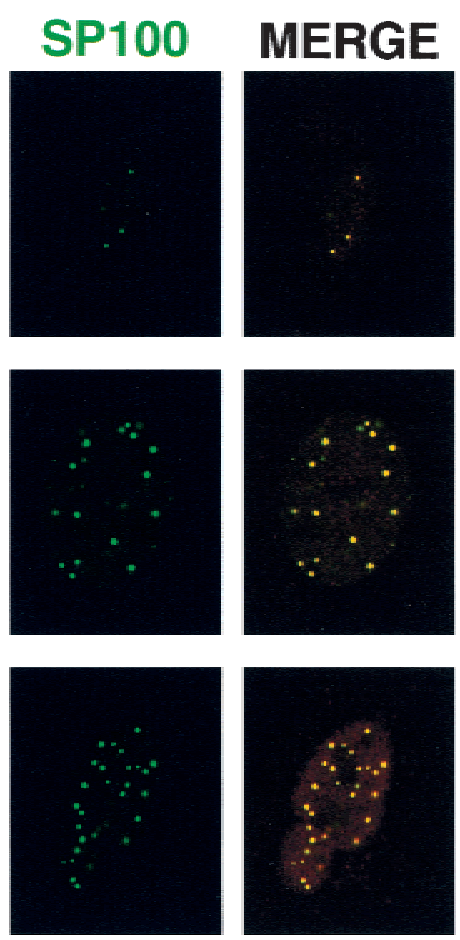

$(12 \pm 3)$
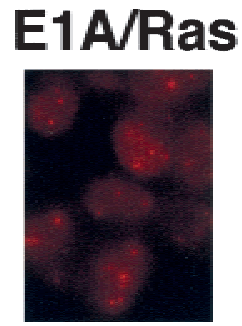

$(4 \pm 2)$
B

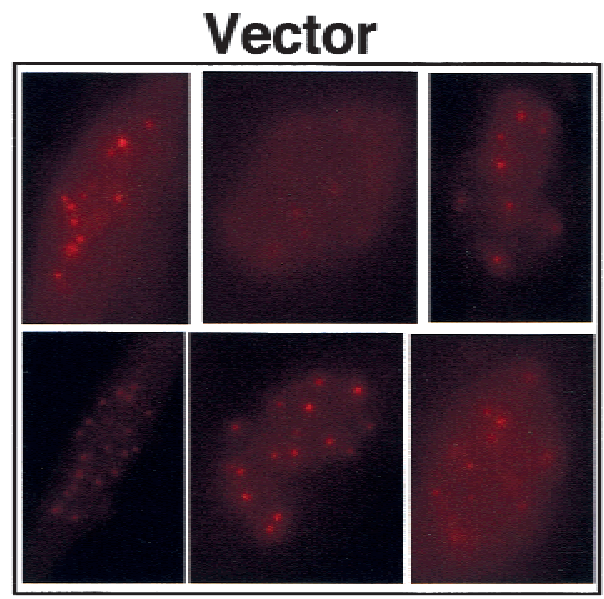

Ras
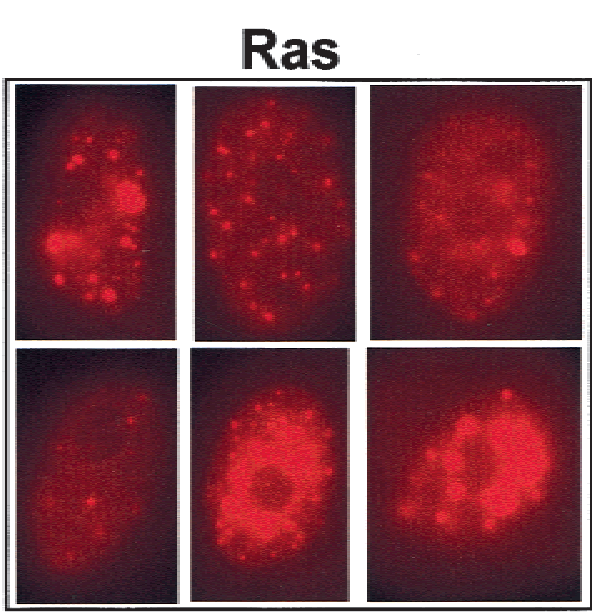

p53

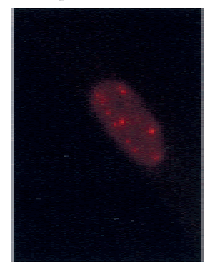

$(11 \pm 5)$
E

Ras (days post-selection)

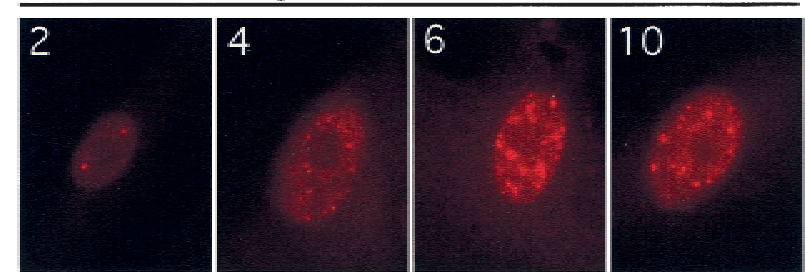

SA- $\beta$-gal $(4 \pm 2)$

$(75 \pm 5)$

$(95 \pm 4)$

$(98 \pm 3)$

Figure 2. PODs accumulate during premature senescence. PML and Sp100 localization in IMR90 cells was determined by indirect immunofluorescence using the PGM3 monoclonal antibody and the rabbit Anti-Sp100 polyclonal antibody AB1380. To facilitate comparison, photomicrographs of each cell were prepared using identical microscope settings and exposure times. In all instances, similar results were obtained with a polyclonal antibody directed to a different epitope of human PML (see Materials and Methods). (A) Confocal images of costaining for PML and Sp100 in cells expressing an empty vector (V), oncogenic ras (R) and senescent cells (S). (B) PML staining in a representative series of cells expressing an empty vector (V) and oncogenic ras (R). (C) PML staining in exponentially growing subconfluent (SC) cells was compared to cells arrested by confluence (C), low serum (LS), or enforced p53 expression. (D) PML staining in cells expressing E1A or coexpressing E1A and oncogenic ras. (E) PML staining of ras-expressing cells fixed $2,4,6$, and 10 days after selection for cells expressing oncogenic ras. In panels $B-D$, the percentage of SA- $\beta$-gal positive cells in each population is indicated below each picture. 

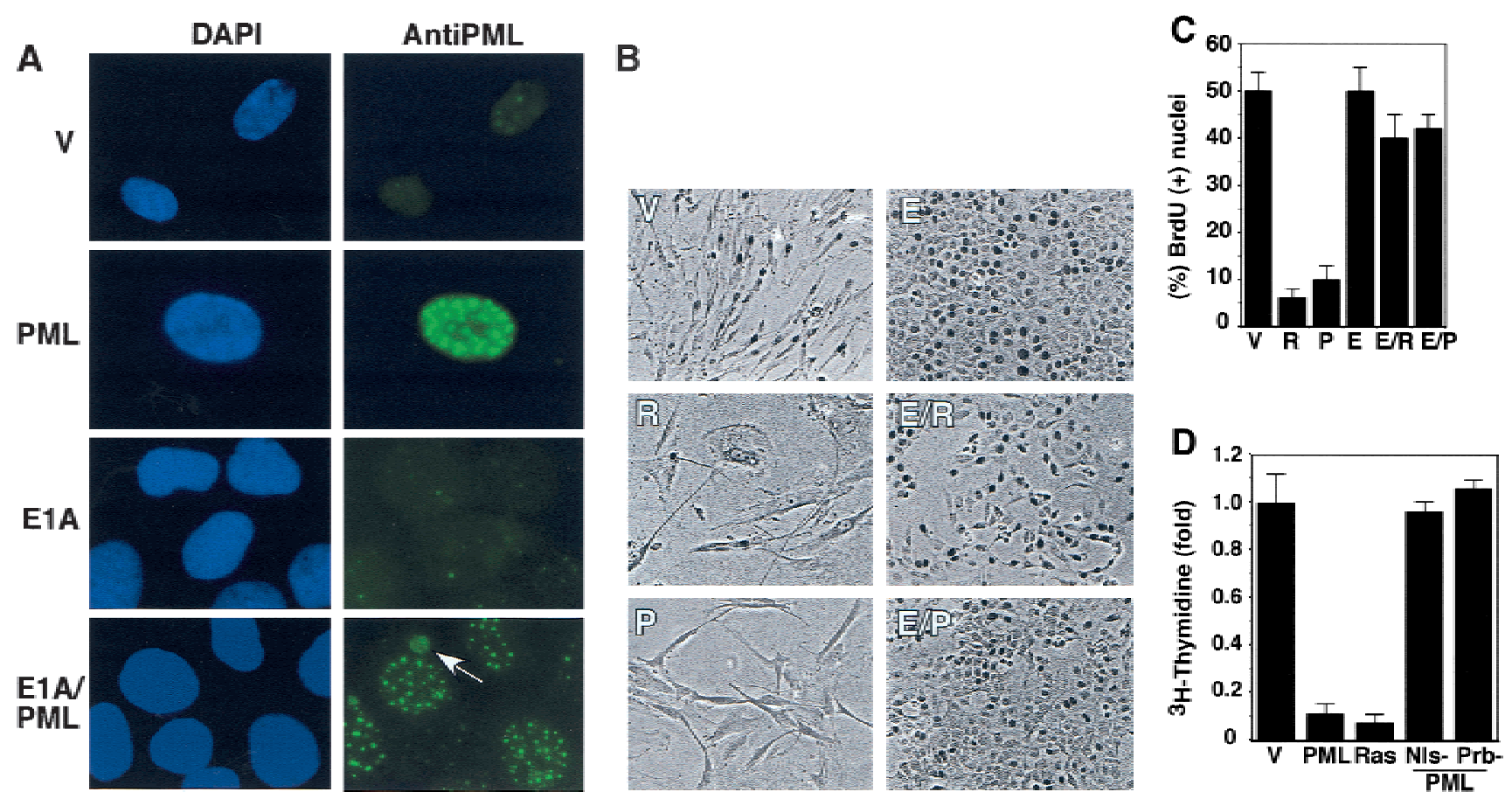

Figure 3. Impact of enforced $P M L$ expression on IMR90 cells. (A) IMR90 cells or IMR90 cells expressing E1A were infected with a control vector $(\mathrm{V})$ or a virus expressing PML. PML staining and POD structure were visualized by indirect immunofluorescence using 4'6-diamidino-2-phenylindole (DAPI) staining to highlight the nucleus. Representative samples are shown. The arrow in the bottom right panel (E1A) points to a cytoplasmic PML conglomerate. (B) Cell morphology and in situ bromodeoxyuridine (BrdU) incorporation of control IMR90 cells or E1A-expressing IMR90 (E1A) cells infected with an empty vector (V), or viruses expressing oncogenic ras (R) or PML (P). The cells were pulsed with $10 \mu \mathrm{M}$ BrdU for 2 hours a day 4 postselection, and BrdU incorporation was visualized using immunohistochemistry. (C) Quantitation of the results presented in $B$, showing the percentage of BrdU-positive nuclei. The average and standard deviation of three independent counts of 200 cells are shown. The abbreviations are as follows: (V) vector; (R) oncogenic ras; (P) PML; (E) E1A. (D) ${ }^{3} \mathrm{H}$-thymidine incorporation in cells containing a vector control (V), $P M L$, oncogenic ras, or two $P M L$ mutants, $P M L$ Nls- and $P M L$ prb-. All cell populations were pulsed with ${ }^{3} \mathrm{H}$-thymidine for 24 hours, beginning 3 days postselection and the amount of incorporation was measured as described in Materials and Methods. Each point represents the mean \pm standard deviation of data obtained in three independent experiments.

and never reached the densities observed in ras-expressing cells (Fig. 4A, squares). However, upon achieving arrest, cells expressing either oncogenic ras or PML displayed similar cell-cycle profiles, with a prominent $\mathrm{G}_{1} /$ $\mathrm{G}_{2}$ arrest and loss of $\mathrm{S}$ phase DNA content (Fig. 4B). $P M L$ induced the accumulation of SA- $\beta$-gal and the senescence-related form of PAI-1, although the intensity of each marker was not as intense as that produced by oncogenic ras (Fig. 5). Thus, PML is sufficient to promote cell-cycle arrest and premature senescence. These results show that the biological properties of ras- and PMLarrested cells are highly similar and are consistent with a causal role for PML in ras-induced senescence.

\section{$P M L$ activates the $R b$ and the p53 tumor suppressor pathways}

Previous studies demonstrate that the $\mathrm{Rb}$ and $\mathrm{p} 53$ pathways contribute to premature senescence induced by oncogenic ras (Serrano et al. 1997; Lin et al. 1998; Zhu et al. 1998; Morales et al. 1999). Rb is an active growth inhibitor in its hypophosphorylated form, leading to repression of E2F-responsive genes (Dyson 1998). Like cells arrested by oncogenic ras, cells arrested by $P M L$ expressed only hypophosphorylated $\mathrm{Rb}$ and no cyclin $\mathrm{A}$, an E2F-dependent gene (Fig. 6A) (Vigo et al. 1999). Although these changes can be passively associated with cell-cycle arrest, both oncogenic ras and $P M L$ also induced $\mathrm{p} 16^{\mathrm{INK} 4 \mathrm{a}}$, a cyclin-dependent kinase inhibitor that actively prevents $\mathrm{Rb}$ phosphorylation and is not induced during most cell-cycle arrests (Serrano 1997). Hence, PML appears to actively engage the $\mathrm{Rb}$ tumor suppressor pathway.

p53 is activated by a variety of signals, some of which produce specific $\mathrm{p} 53$ posttranslational modifications (Giaccia and Kastan 1998; Prives 1998). For example, p53 phosphorylation on serine 15 accumulates following DNA damage and during replicative senescence (Shieh et al. 1997; Siliciano et al. 1997; Webley et al. 2000) and may activate p53 by compromising the Mdm2-p53 interaction and increasing the affinity of p53 for the CBP transcriptional coactivator (Lambert et al. 1998; Dumaz and Meek 1999). Consistent with previous reports (Serrano et al. 1997; Lin et al. 1998), oncogenic ras induced p53 protein, which corresponded to an increase in the p53 transcriptional targets p21 and Mdm2 (Fig. 6A-C, cf. 
Ferbeyre et al.
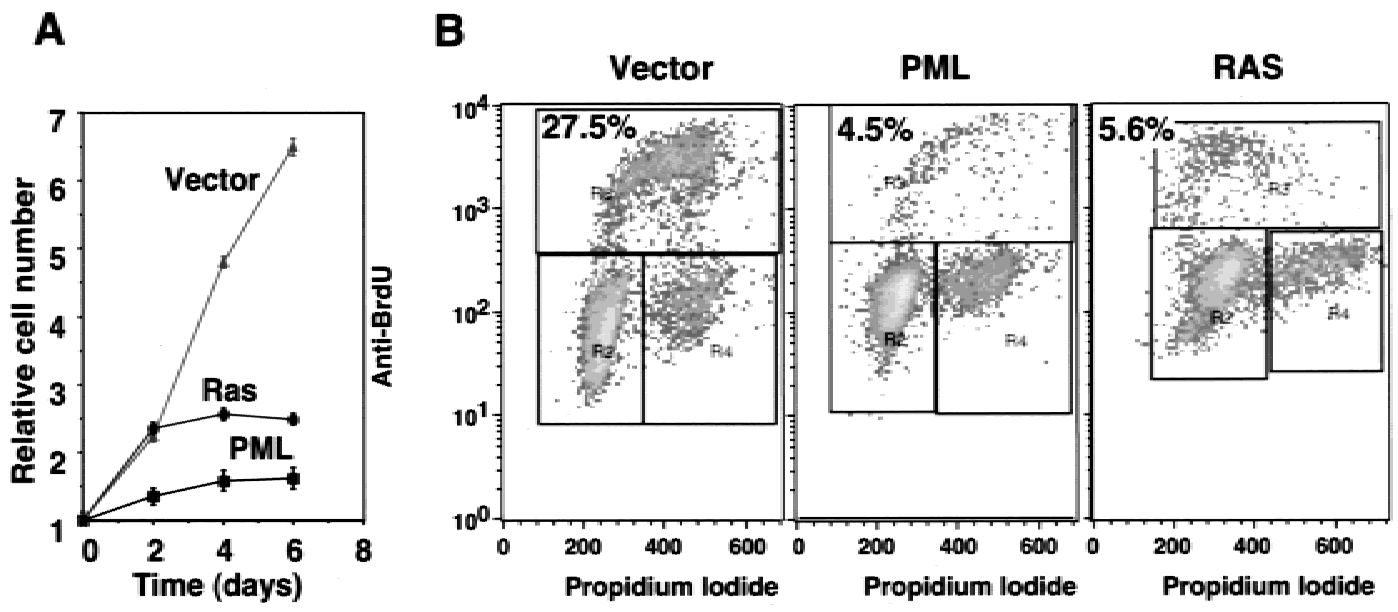

Figure 4. Characteristics of $P M L$-induced arrest. $(A)$ Growth curves of IMR90 cells containing empty vector $(\sigma)$, oncogenic ras $(\lambda)$ or $P M L(v)$. Each value was determined in triplicate and normalized to the cell number at day 0, which corresponded to the time in which the cells finished drug selection. (B) Cell-cycle analysis of populations containing an empty vector, oncogenic ras or PML. The cells were pulsed with BrdU for 4 hours and analyzed for BrdU uptake and DNA content by two-color flow cytometry using a fluorescein isothiocyanate (FITC)-conjugated anti-BrdU antibody and propidium iodide (see Materials and Methods). The percentage of BrdU incorporation is indicated at the top of each panel.

lanes $\mathrm{V}$ and R). Forced $P M L$ expression produced a similar effect, albeit to a lesser degree (Fig. 6A-C, lane P). To determine whether oncogenic ras or PML promote p53 phosphorylation on serine 15 , immunoblotting was performed using antibodies that specifically recognize phosphoserine-15 p53 (PS-15 p53). PS-15 p53 was barely detectable in control cells but was dramatically induced by oncogenic ras (Fig. 6C, cf. lanes V and R). In contrast, induction of $\mathrm{p} 53$ protein by retroviral transduction of p53 produced no increase in PS-15 p53 (Fig. 6C, lane p53). Although $P M L$ induced only a modest accumulation of p53 protein, this was accompanied by a substantially greater increase in PS-15 p53 (Fig. 6C, cf. lanes V and P). Of note, the effect of $P M L$ on PS-15 was more apparent in cells expressing ectopic p53 (Fig. 6C, p53 +P). Consistent with our previous results (de Stanchina et al. 1998), PS15 p53 was not detected in IMR90 cells expressing E1A (Fig. 6D, lane E). In fact, E1A suppressed the accumulation of PS-15 p53 in response to oncogenic ras (Fig. 6D, lanes $\mathrm{R}$ and ER). This suppression may involve the E1Ap300/CBP interaction, for cells expressing E1A mutants unable to bind p300/CBP induced PS-15 p53 (data not shown). Therefore, like oncogenic ras, $P M L$ can activate the p53 tumor suppressor pathway in a manner that is modulated by E1A.

\section{Oncogenic ras and PML promote $R b$ and $p 53$ relocalization to the PODs}

PML can modulate transcription by recruiting transcription factors to the PODs, and both $\mathrm{Rb}$ and p53 can localize to PODs under certain circumstances (Alcalay et al. 1998; Lain et al. 1999). To determine whether endogenous $\mathrm{PML}$ colocalizes with $\mathrm{Rb}$ during premature senescence, we conducted confocal laser scanning immunofluorescence microscopy on control /vector only) and ras-arrested cells using a PML monoclonal antibody and a polyclonal antibody that recognizes the carboxyl terminus of $\mathrm{Rb}$. In both vector-control and ras-arrested cells, $\mathrm{Rb}$ was predominantly observed in small nuclear speckles that displayed no obvious overlap with the PODs (Fig. 7A). However, a portion of Rb in ras-arrested cells formed larger nuclear bodies that colocalized with the PODs or were immediately adjacent to them. Although only a relatively small percentage of PODs contained $\mathrm{Rb}$ in ras-arrested cells, it was highly reproducible and represented a tenfold increase relative to that observed in controls $14 \%$ vs. $1 \%$, respectively).

To determine whether PML colocalized with p53 during ras-induced arrest, a similar series of experiments were performed using antibodies against PML and p53. Although p53 did not colocalize with PML in control cells, a striking colocalization of p53 and PML was observed in ras-arrested cells (Fig. 7B). Only a subset of the endogenous p53 associated with the PODs, but each POD contained p53. To confirm and extend this result, IMR90 cells were coinfected with retroviruses expressing a p53-GFP fusion protein and retroviruses expressing either oncogenic ras or PML. Upon the induction of premature senescence, the localization of p53 and PML were determined by confocal fluorescence microscopy using GFP or antibodies against PML. As expected, p53GFP was expressed in the nucleus of control (vector only) cells and oncogenic ras promoted colocalization of a subset of GFP with PML (Fig. 7C). Virtually all of the p53GFP colocalized with the PODs in $P M L$-arrested cells, implying that PML can force p53 re-localization to the PODs. The fact that both oncogenic ras and PML can promote relocalization of p53 to the PODs is consistent with a role for PML in ras-induced arrest and may explain how PML activates p53. 
A
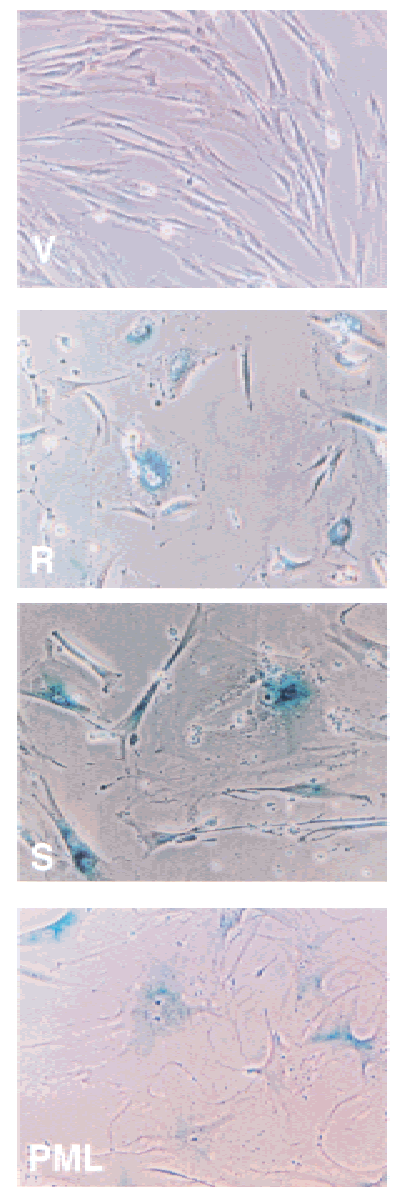

C

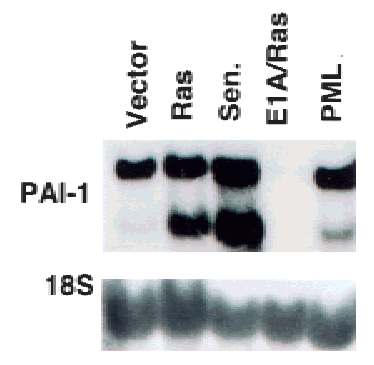

Figure 5. $P M L$ induces premature senescence. $(A)$ IMR90 cell populations containing an empty vector $(\mathrm{V})$, oncogenic ras $(\mathrm{R})$ or $P M L$ were stained for SA- $\beta$-gal 6 days postselection. IMR90 cells that were serially passaged until senescent $(S)$ are shown for comparison. Representative photomicrographs are shown; senescent-cells display a cytoplasmic blue stain. $(B)$ Quantitation of data in $A$, showing the percentage of SA- $\beta$-gal positive cells. The data represent the mean \pm standard deviation of three independent counts of 200 cells. (C) Expression of PAI-1 in the indicated populations was measured by Northern blot.

\section{Discussion}

\section{PML contributes to premature senescence}

Expression of oncogenic ras in human diploid fibroblasts triggers a premature senescence program that limits the promitogenic consequences of excessive Ras signaling. Using a differential gene expression screen, we identified the candidate tumor suppressor $P M L$ as a gene up-regulated during ras-induced senescence. Several observations suggest that PML actively contributes to this program. First, the onset of cellular senescence is accompanied by a striking increase in size and number of the PODs. This increase is relatively specific for cells undergoing senescence, because PODs accumulate during replicative senescence (see also, Jiang and Ringertz 1997) but not during the nonsenescent arrests induced by

growth factor withdrawal, contact inhibition, or p53 overexpression. Second, like oncogenic ras, forced expression of $P M L$ is sufficient to induce premature senescence. Hence, PML induction is not simply associated with the senescent state. Third, as in ras-induced arrest, $P M L$-induced arrest is accompanied by engagement of the $\mathrm{Rb}$ and p53 tumor suppressor pathways. Both oncogenic ras and $P M L$ induce $\mathrm{p} 16, \mathrm{Rb}$ hypophosphorylation, PS-15 p53, and p53 transcriptional targets. Fourth, oncogenic ras promotes the relocalization of a subset of $\mathrm{Rb}$ and p53 to the PODs. Finally, E1A, which overrides rasinduced arrest and disables the $\mathrm{Rb}$ and p53 arrest programs, prevents PML induction by oncogenic ras and abolishes $P M L$-induced arrest. Thus, PML can promote premature senescence and may modify the tumor-suppressor effects of the $\mathrm{Rb}$ and $\mathrm{p} 53$ pathways.

\section{Regulation of $P M L$}

Oncogenic ras induces premature senescence, in part, by constitutively signaling through the MAP Kinase
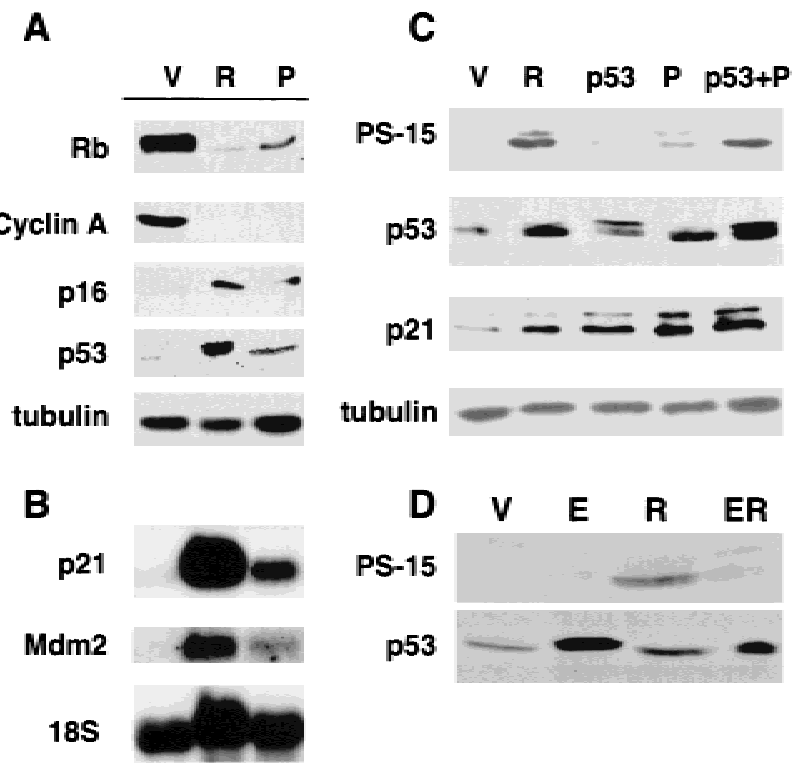

Figure 6. PML engages the $\mathrm{Rb}$ and $\mathrm{p} 53$ pathways. $(A)$ The expression of Rb, cyclin A, p16, and p53 was measured by immunoblotting of lysates from IMR90 cells containing an empty vector $(\mathrm{V})$, oncogenic ras $(\mathrm{R})$ or $P M L(\mathrm{P}) .(B)$ Expression of $\mathrm{p} 53$ targets $\mathrm{p} 21$ and $\mathrm{mdm} 2$ by Northern blot analysis of total RNA extracted from the cells indicated above. $(C)$ p53 phosphorylation on serine 15 was detected by immunoblotting using antibodies that specifically bind PS-15 p53. Lysates were prepared from cells infected with a empty vector $(\mathrm{V})$, oncogenic ras $(\mathrm{R})$, wild-type human p53 (p53), PML (P), or both the p53 and PML expressing viruses $(\mathrm{p} 53+\mathrm{P})$. The expression of total p53 was measured using a polyclonal antibody that recognizes all p53. The expression of the p53-target p21 is shown for comparison. Lysates were prepared from cells containing an empty vector $(\mathrm{V})$, oncogenic ras $(\mathrm{R}), p 53, P M L(\mathrm{P})$ and a combination of $\mathrm{p} 53$ and $P M L(\mathrm{p} 53+\mathrm{P}) \cdot(D)$ The impact of E1A on PS-15 p53 was determined as in $B$, in which (ER) indicates cells co-expressing E1A and oncogenic ras. 

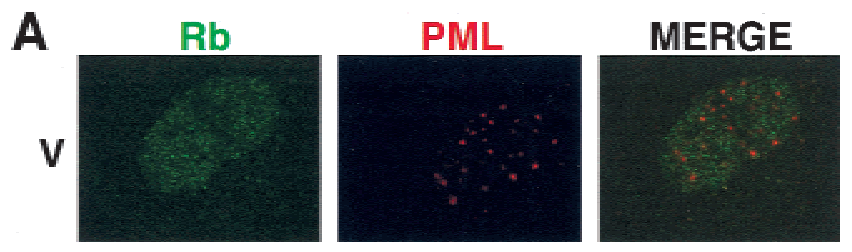

$\mathbf{R}$

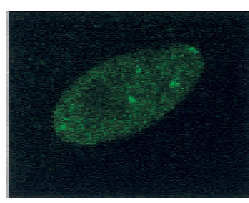

B
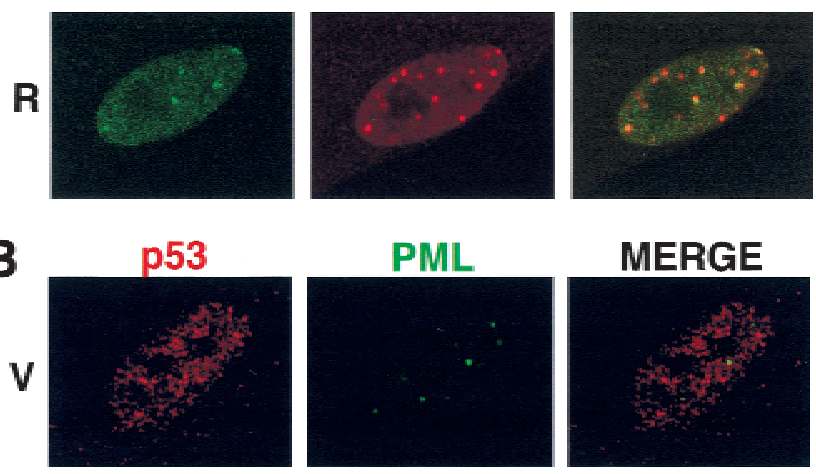

$\mathbf{R}$
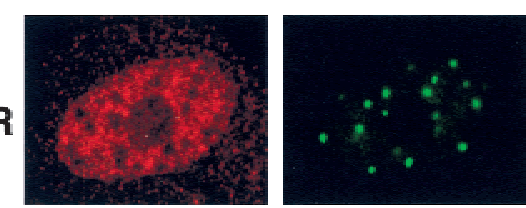
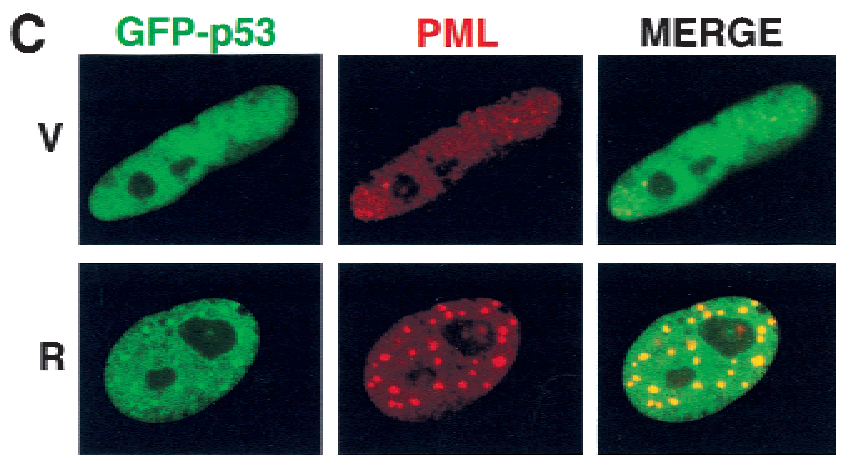

$\mathbf{P}$
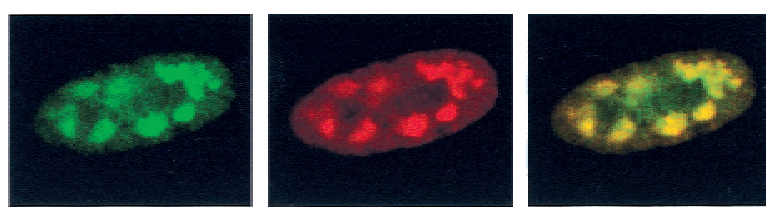
Representative images of cells expressing a p53-green fluorescent protein (GFP) fusion protein and either a control vector (V), oncogenic ras (R), or PML (P). In this series, p53 was localized by direct GFP fluorescence, whereas PML was localized using an anti-PML antibody.

(MAPK) cascade (Lin et al. 1998; Zhu et al. 1998). MAPK signaling also contributes to PML induction, because the size and intensity of the PODs increased after expression of oncogenic raf (data not shown). However, PML bodies are not induced immediately in response to oncogenic ras but appear after an initial mitogenic burst coincident with senescence. These data suggest that Ras signaling to PML is indirect and, like the senescence process itself, reflects a cellular response to some aspect of inappropriate mitogenic signaling. Of note, interferon also induces PML and other components of the PODs /Guldner et al. 1992; Korioth et al. 1995; Lavau et al. 1995; Stadler et al. 1995). Several additional interferon-responsive genes were induced by oncogenic ras on our cDNA arrays, including Sp100, which encodes another POD component (see Fig. 2A)(Guldner et al. 1992). These data raise the possibility that components of the interferon signal transduction program contribute to ras-induced arrest. Consistent with this view, E1A interferes with both ras-induced arrest and interferon signaling (Gutch and Reich 1991; Bhattacharya et al. 1996; Serrano et al 1997), and disruption of the interferon response factor-1 cooperates with oncogenic ras during transformation and tumorigenesis (Tanaka et al. 1994; Nozawa et al. 1999).

\section{PML action in premature senescence}

How PML acts in tumor suppression is not firmly established. Previous studies using human tumor cells or knockout mice suggest that PML can influence cell- cycle control, differentiation, and apoptosis (Dyck et al. 1994; Weis et al. 1994; Wang et al. 1998a,b). None of these PML activities are well understood at the mechanistic level, but it is often assumed that PML acts by recruiting other proteins to the PODs (Zhong et al. 2000). The ability of PML to form PODs appears essential for its prosenescence activity, because two PML mutants unable to form PODs are unable to induce premature senescence. Our results indicate that PML contributes to the control of cellular senescence, in part, by modulating the $\mathrm{Rb}$ and $\mathrm{p} 53$ tumor suppressor pathways (Fig. 8). This, too, may involve the ability of PML to recruit $\mathrm{Rb}$ and p53 to the PODs, because the fraction of p53 and $\mathrm{Rb}$ that colocalizes with PODs dramatically increases in response to oncogenic ras. In principle, these structures might recruit $\mathrm{Rb}$ and $\mathrm{p} 53$ to sites of transcriptional repression or activation, respectively, or they might act as transient docking sites to assemble the active transcription complexes that then migrate to other areas in the nucleus.

Although our data show that PML can engage the $\mathrm{Rb}$ and p53 pathways, they do not show an absolute requirement for either pathway in the arrest; nor do they rule out the possibility that PML has additional effects (Fig. 8). Hence, inactivation of either pathway alone is unable to override premature senescence (data not shown; Serrano et al. 1997). Furthermore, it is possible that PML itself is not required for premature senescence, because all attempts to disable PML function using antisense inhibition or putative dominant-negative proteins were unable to override ras-induced arrest (data not shown). 


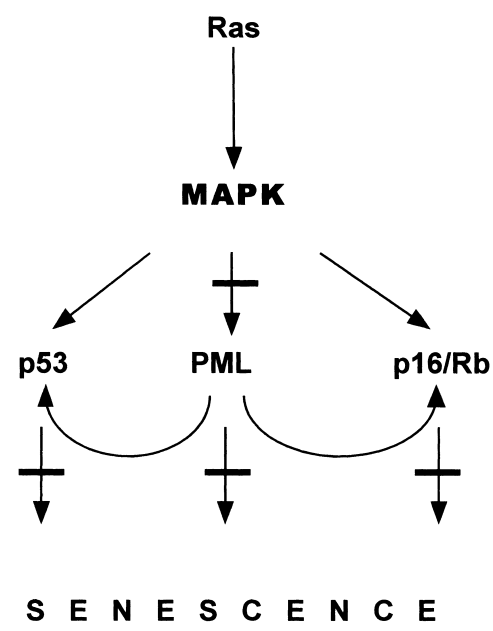

Figure 8. A tumor suppressor network is activated by oncogenic ras and inhibited by E1A in human diploid fibroblasts. Expression of oncogenic ras in human diploid fibroblasts induces first uncontrolled proliferation and then a permanent cellcycle arrest with characteristics of cellular senescence. The process involves the mitogen-associated protein (MAP) kinase pathway (Lin et al. 1998) and the tumor suppressors p53, p16, Rb (Serrano et al. 1997) and PML (this paper). PML modulates both the $\mathrm{Rb}$ and $\mathrm{p} 53$ pathways but may have additional activities. Lesions that alter individual tumor suppressors in isolation do not override ras-induced arrest (Serrano et al. 1997; Morales et al. 1999). However, E1A disables multiple tumor-suppressor pathways and, hence, overrides ras-induced arrest (see bars).

We suspect that in human cells inactivation of both the $\mathrm{Rb}$ and p53 pathways is required to circumvent $P M L$ induced arrest. E1A abolishes the Rb pathway by binding $\mathrm{Rb}$ (Whyte et al. 1988) and interferes with the p53 cellcycle arrest checkpoint (Lowe et al. 1993), perhaps through the E1A-p300/CBP interaction (Lill et al. 1997). Thus, E1A interferes with both the p53 and Rb growth arrest pathways and abrogates ras- and $P M L$-induced arrest (Fig. 3; see also Serrano et al. 1997). Nevertheless, E1A may also interfere with an $\mathrm{Rb}$ - and p53-independent activity of PML.

Together, our data indicate that the control of premature senescence in human cells involves a tumor-suppressor network rather than a single antiproliferative pathway (Fig. 8). This tight control of ras-induced senescence in human cells is in contrast to the more relaxed control observed in murine cells, in which induction of ras-induced arrest depends strictly on the ARF-p53 pathway (Serrano et al. 1997; Palmero et al. 1998). Interestingly, in MEFs, oncogenic ras induces PML in a p53dependent manner, and p53 is required for $P M L$-induced arrest (E. Querido and S.W.Lowe, unpubl.). This observation is reminiscent of the ability of E1A to prevent both PML accumulation and PML-induced arrest and suggests that PML may operate in a positive-feedback loop that ultimately leads to a permanent cell-cycle arrest. We suspect that the more stringent control of premature senescence in human cells relates to the more prominent role of the $\mathrm{Rb}$ pathway. Accordingly, disruption of $\mathrm{p} 53$ alone immortalizes rodent cells, whereas the ability of certain viral oncoproteins to evade replicative senescence in human cells depends, in part, on their ability to bind $\mathrm{Rb}$ (Morales et al. 1999).

\section{Implications for $p 53$ regulation and activity}

Oncogenic ras induces p53 levels and activity, in part, through the MAPK cascade (Lin et al. 1998). The data presented here imply that PML contributes to p53 activation, perhaps by recruiting p53 to the PODs (see above). Importantly, PML is unable to increase p53 levels to the extent produced by oncogenic ras, implying that another ras-inducible factor contributes to p53 activation. An obvious candidate for this activity is p14 ${ }^{\mathrm{ARF}}$, which is essential for p53 activation and ras-induced arrest in MEFs (Palmero et al. 1998). However, we have been unable to detect p14 ${ }^{\mathrm{ARF}}$ induction by oncogenic ras in human diploid fibroblasts, raising the possibility that a different factor cooperates with PML to stabilize p53.

PML has a potent ability to force p53 to the PODs (Fig. 7); this may result from a direct protein-protein interaction (G. del Sal, pers. comm.). Furthermore, like oncogenic ras, PML is able to promote the phosphorylation of p53 on serine 15. This effect is likely indirect, because PML is not known to possess kinase activity. SP-15 p53 displays an increased ability to associate with CBP (Lambert et al. 1998), a known POD component and p53 transcriptional coactivator (Lill et al. 1997; LaMorte et al. 1998). In principle, serine 15 phosphorylation might actively recruit p53 to the PODs or, alternatively, might occur as a consequence of p53 relocalization. In any case, the ability of E1A to suppress serine-15 phosphorylation correlates with its ability to circumvent ras-induced arrest. Interestingly, ectopic p53 expression at levels similar to that produced by oncogenic ras did not induce PS-15 p53 or senescence (Figs. 3B,6B), raising the provocative possibility that PML converts p53 into a senescence inducer.

\section{Implications for multistep carcinogenesis}

In summary, our results indicate that PML participates in the control of cellular senescence and further define the mechanism of ras-induced arrest. In human cells, this program involves multiple tumor-suppressor proteins that form a tumor-suppressor network of activities working on and reinforcing each other (Fig. 8). As a consequence, growth suppression is tightly controlled and difficult to overcome. Although loss-of-function mutations in $P M L$ have not been described, PML dysfunction produced by the PML-RAR $\alpha$ fusion protein promotes neoplasia, and $P M L$ inactivation produces tumor-prone mice (reviewed by Melnick and Licht 1999). Interestingly, $P M L$-null mice are highly prone to papilloma formation following skin treatment with the carcinogen dimethylbenzanthracene and the tumor promoter 12-Otetradecanoylphorbol-13-acetate (Wang et al. 1998b). Because this experimental paradigm inevitably produces ras mutations, these results imply that oncogenic ras 
and $P M L$ inactivation cooperate during tumor development. Together, these data establish a new activity of PML that may be important in tumor suppression.

\section{Materials and methods}

\section{Cells and retroviruses}

Normal human diploid fibroblasts IMR90 (PDL 22-25) expressed the murine ecotropic receptor to allow infection with murine retroviruses (Serrano et al. 1997). They were cultured in Dulbecco's modified Eagle medium (DMEM, GIBCO) supplemented with $10 \%$ fetal bovine serum (FBS, Hyclone, Utah) and $1 \%$ penicillin G/streptomycin sulfate (Sigma). Retroviral-mediated gene transfer was performed using Phoenix packaging cells as previously described (Serrano et al. 1997). Oncogenic ras (HRasV12) was expressed using pBabe-ras or pWZL-ras (Serrano et al. 1997). PML (Mu et al. 1994), PMLnls- and PMLprb- (provided by Dr. K.S. Chang) were expressed using pLPC or pWZL Hygro (McCurrach et al. 1997). E1A was expressed using pLPC-12S (Samuelson and Lowe 1997). Human p53 was expressed using either pLPC-hp53 (McCurrach et al. 1997) or p53GFP (provided by G. Hannon). Infected cell populations were selected in either puromycin $(2.5 \mu \mathrm{g} / \mathrm{ml}, 3$ days $)$ or hygromycin $(100 \mu \mathrm{g} / \mathrm{ml}, 5$ days).

\section{Gene expression}

Cells used for differential gene expression studies were prepared as follows: IMR90 cells were infected with retroviruses expressing oncogenic ras (Babe-ras) or an empty vector control (Babepuro). Infected cell populations were selected in puromycin for 2 days. Three days postselection, the cells were subcultured 1:3 and cultured for another 7 days. Under these conditions, control populations become highly confluent and arrest by contact inhibition, whereas ras-expressing cells arrest at subconfluent density. In these test populations, cell-cycle arrest was confirmed by ${ }^{3} \mathrm{H}$-thymidine incorporation (see below), and senescence was confirmed by quantifying the percentage of cells that were positive for SA- $\beta$-gal (Dimri et al. 1995). mRNA was extracted from cells 10 days postselection (PolyATtract system 1000, Promega), and hybridization probes were prepared from $2.5 \mu \mathrm{g}$ of mRNA by reverse transcription in the presence of ${ }^{33} \mathrm{P}-\alpha \mathrm{dCTP}$. Differential gene expression was assessed using Genome Discovery Arrays (GDA 1.2, Genome Systems) containing 18,376 cDNAs according to the manufacturers recommendations. Data were collected in a Molecular Dynamics PhosphorImager and the files were sent electronically to the manufacturer for analysis

The overall quality of the data was estimated from the ability of our results to identify known changes induced during cellular senescence. The genes for PAI-1 (Goldstein et al. 1994; Mu and Higgins 1995), interleukin-1 $\beta$ (Kumar et al. 1993), stromelysin (Millis et al. 1992), p21 (Noda et al. 1994), and SOD (Chang et al. 2000) were all found up-regulated in ras-expressing cells. In addition, we detected similar changes in expression of nonoverlapping ESTs corresponding to the same gene. To validate specific changes, Northern blots were conducted using total RNA purified using RNAzol, (Biotecx Labs, Houston, Texas). Twenty $\mu \mathrm{g}$ of total RNA was fractionated on $1.2 \%$ formaldehyde-agarose gels and transferred to Hybond-N nylon membranes (Amersham) in $20 \times$ SSC $(1 \times$ SSC is $0.15 \mathrm{M} \mathrm{NaCl}, 0.015 \mathrm{M}$ sodium citrate at $\mathrm{pH} 7.0$, and $0.1 \%$ SDS). Hybridization was performed at $65^{\circ} \mathrm{C}$ with ${ }^{32} \mathrm{P}$-labeled probes in $7 \%$ SDS, $0.25 \mathrm{M}$ phosphate buffer (pH 7.4), $1 \%$ BSA and 1 mM EDTA. The membranes were washed twice at $65^{\circ} \mathrm{C}$ in $2 \times$ SSC for $10 \mathrm{~min}$ and once in $0.2 \times$ SSC for $30 \mathrm{~min}$. Probes for PML, stromelysin, and IL-1 $\beta$ consisted of overlapping 60 mer oligonucleotides and were labeled using Klenow polymerase as described (Wong and Goeddel 1994). The sequences of these probes are available upon request. The probes for PAI-1 (Serrano et al. 1997) and 18S rRNA were labeled by random priming (T7 QuickPrime, Pharmacia Biotech, Inc.).

\section{Cell proliferation}

Cell proliferation was assessed using several assays. For growth curves, cells were plated at $2.5 \times 10^{4}$ per well in 12 -well plates, and relative cell numbers were estimated at various times using a crystal violet incorporation assay as previously described (Serrano et al. 1997). To assess ${ }^{3} \mathrm{H}$-thymidine incorporation, cells were plated as above at day- 3 postselection. After $12 \mathrm{hrs}$, the cells were pulsed for $24 \mathrm{hrs}$ with $5 \mu \mathrm{Ci} / \mathrm{ml}$ [methyl- $\left.{ }^{3} \mathrm{H}\right]$-thymidine (Amersham, 2Ci/mM), washed with PBS, and detached using trypsin. Incorporated ${ }^{3} \mathrm{H}$-thymidine was precipitated in the presence of ice-cold $10 \%$ TCA for 5 min, collected on glass-fiber filters (Filtermat, Wallac), and quantified by scintillation counting. To generate cell-cycle profiles of various populations, subconfluent cultures (day-4 postselection) were incubated in the presence of $10 \mu \mathrm{M} \mathrm{BrdU}$ (Amersham) for $4 \mathrm{hr}$, fixed, and prepared for flow cytometry as previously described (Lin et al. 1998). To visualize BrdU incorporation in situ, subconfluent cultures were incubated for $2 \mathrm{hrs}$ in the presence of $10 \mu \mathrm{M} \mathrm{BrdU}$, fixed, and nuclei incorporating BrdU were visualized by immunostaining using a commercially available kit (Cell proliferation kit, Amersham Pharmacia Biotech).

\section{Protein expression}

Immunoblots were performed from whole cell lysates as previously described (de Stanchina et al. 1998). $20 \mu \mathrm{g}$ of protein/ sample were resolved on SDS-PAGE gels and transferred to Immobilon-P membranes (Millipore). Antibodies against p53 (CM1, 1:2500, Novocastra), PS-15 p53 (16G8, 1:1000, New England Biolabs), p21 (C19, 1:500, Santa Cruz), Ras (OP23, 1:500, Calbiochem) p16 (DCS-50, Novocastra, 1:200), Rb (G3-245; Pharmigen, 1:1000), cyclin A (BF683, Santa Cruz, 1:500), Mdm2 (2A10, provided by A. Levine, 1:250), and $\alpha$-tubulin (B-5-1-2, Sigma, 1:2000) were used as probes and detected using enhanced chemiluminescence (ECL, Amersham, or SuperSignal West Femtomaximum, Pierce). To detect PML, we used a monoclonal antibody (PGM-3, 1:500, Santa Cruz) raised against amino acids $37-51$ or a rabbit polyclonal antibody (provided by K.S. Chang, 1:500) directed against amino acids 352-366.

\section{Fluorescence microscopy}

Cells were plated on coverslips for at least $24 \mathrm{hr}$ and fixed using $4 \%$ paraformaldehyde in PBS for $15 \mathrm{~min}$ at room temperature. After washing with PBS, cells were permeablized for $5 \mathrm{~min}$ on ice with $0.2 \%$ Triton X-100 in PBS with $3 \%$ BSA (PBS/BSA). Then the cells were washed with PBS/BSA and incubated for 1 hr with different primary antibodies diluted in PBS/BSA, antip53 (CM1, 1:50, Novocastra), anti-Rb (aRB1C1, 1:50, provided by G. Klein), anti-PML (PGM-3, 1:200, Santa Cruz), anti-PML rabbit polyclonal (provided by K.S. Chang, 1:1000) and antiSp100 (AB1380, Chemicon Int., 1:500). After washing in PBS/ BSA, cells were stained with FITC or Texas Red-conjugated secondary antibodies, $(1: 200)$ for $45 \mathrm{~min}$ at room temperature in a humidified chamber. Finally, cells were washed in PBS, stained with 4,6-diamidino-2-phenylindole (DAPI) at a concentration of 
$0.1 \mu \mathrm{g} / \mathrm{ml}$ in PBS and mounted on microscope slides. For standard fluorescence detection, we used a Zeiss immunofluorescence microscope (Axioscop 50, Thornwood, NY). Confocal images were obtained using a Zeiss LSM 510 confocal laser scanning microscope (Thornwood, NY) using simultaneous scans to avoid shift between the two optical channels. Data were collected with eightfold averaging at a resolution of $512 \times 512$ pixels using the LSM 510 software and exported for printing using Adobe Photoshop.

\section{Acknowledgments}

We thank V. Bourdeau for advice and extensive technical assistance; G. del Sal for discussing unpublished work; K.S. Chang, G. Hannon, G. Klein, and A. Levine for reagents; J. Hearing for assistance with the Molecular Dynamics PhosphorImager; D. Spector, B. Stillman, W. Herr, M. Hengartner, G. Hannon, and members of the Lowe Laboratory for helpful comments and discussion; K. Velinzon of the (CSHL) Flow Cytometry Shared Resource for technical assistance; T. Howard of the CSHL Microscopy Shared Resource for extensive advice and assistance; and M. Ockler, P. Renna, and J. Duffy of the CSHL Graphic Arts Shared Resource for assistance in preparing the figures. G.F. is a Tularik Fellow, E.dS. is a Human Frontier Science Fellow, and S.W.L. is a Rita Allen Foundation Scholar. This work was supported by grant AG-16379 from the National Institutes of Health.

The publication costs of this article were defrayed in part by payment of page charges. This article must therefore be hereby marked "advertisement" in accordance with 18 USC section 1734 solely to indicate this fact.

\section{Note added in proof}

Pearson et al. (Nature 406: 207-210) have recently shown that $\mathrm{PML}$ is required for ras-induced arrest in murine fibroblasts.

\section{References}

Alcalay, M., Tomassoni, L., Colombo, E., Stoldt, S., Grignani, F., Fagioli, M., Szekely, L., Helin, K., and Pelicci, P.G. 1998. The promyelocytic leukemia gene product (PML) forms stable complexes with the retinoblastoma protein. Mol. Cell. Biol. 18: 1084-1093.

Artandi, S.E. and DePinho, R.A. 2000. A critical role for telomeres in suppressing and facilitating carcinogenesis. Curr. Opin. Genet. Dev. 10: 39-46.

Bhattacharya, S., Eckner, R., Grossman, S., Oldread, E., Arany, Z., D'Andrea, A., and Livingston, D.M. 1996. Cooperation of Stat 2 and $\mathrm{p} 300 / \mathrm{CBP}$ in signalling induced by interferon-alpha. Nature 383: 344-347.

Campisi, J. 1997. The biology of replicative senescence. Eur. J. Cancer 33: 703-709.

Chang, B.D., Broude, E.V., Dokmanovic, M., Zhu, H., Ruth, A., Xuan, Y., Kandel, E.S., Lausch, E., Christov, K., and Roninson, I.B. 1999. A senescence-like phenotype distinguishes tumor cells that undergo terminal proliferation arrest after exposure to anticancer agents. Cancer Res. 59: 3761-3767.

Chang, B.D., Watanabe, K., Broude, E.V., Fang, J., Poole, J.C., Kalinichenko, T.V., and Roninson, I.B. 2000. Effects of p21Waf1/Cip1/Sdi1 on cellular gene expression: implications for carcinogenesis, senescence, and age-related diseases. Proc. Nat1. Acad. Sci. 97: 4291-4296.

de Stanchina, E., McCurrach, M.E., Zindy, F., Shieh, S.Y., Ferbeyre, G., Samuelson, A.V., Prives, C., Roussel, M.F., Sherr, C.J., and Lowe, S.J. 1998. E1A signaling to p53 involves the p19(ARF) tumor suppressor. Genes \& Dev. 12: 2434-2442. de The, H., Lavau, C., Marchio, A., Chomienne, C., Degos, L., and Dejean, A. 1991. The PML-RAR alpha fusion mRNA generated by the $t(15 ; 17)$ translocation in acute promyelocytic leukemia encodes a functionally altered RAR. Cell 66: 675-684.

Dimri, G.P., Lee, X., Basile, G., Acosta, M., Scott, G., Roskelle, C., Medrano, E.E., Linskens, M., Rubelj, I., Pereira-Smith, O., Peacocke, M., and Campisi, J. 1995. A biomarker that identifies senescent human cells in culture and in aging skin in vivo. Proc. Natl. Acad. Sci. 92: 9363-9367.

Dimri, G.P., Itahana, K., Acosta, M., and Campisi, J. 2000. Regulation of a senescence checkpoint response by the E2F1 transcription factor and p14(ARF) tumor suppressor. Mol. Cell. Biol. 20: 273-285.

Doucas, V., Tini, M., Egan, D.A., and Evans, R.M. 1999. Modulation of CREB binding protein function by the promyelocytic (PML) oncoprotein suggests a role for nuclear bodies in hormone signaling. Proc. Nat1. Acad. Sci. 96: 2627-2632.

Dumaz, N. and Meek, D.W. 1999. Serine15 phosphorylation stimulates p53 transactivation but does not directly influence interaction with HDM2. EMBO J. 18: 7002-7010.

Dyck, J.A., Maul, G.G., Miller, Jr., W.H., Chen, J.D., Kakizuka, A., and Evans, R.M. 1994. A novel macromolecular structure is a target of the promyelocyte- retinoic acid receptor oncoprotein. Cell 76: 333-343.

Dyson, N. 1998. The regulation of E2F by pRB-family proteins. Genes \& Dev. 12: 2245-2262.

Evan, G.I., Wyllie, A.H., Gilbert, C.S., Littlewood, T.D., Land, H., Brooks, M., Waters, C.M., Penn, L.Z., and Hancock, D.C. 1992. Induction of apoptosis in fibroblasts by c-myc protein. Cell 69: 119-128.

Giaccia, A.J. and Kastan, M.B. 1998. The complexity of p53 modulation: Emerging patterns from divergent signals. Genes \& Dev. 12: 2973-2983.

Goddard, A.D., Borrow, J., Freemont, P.S., and Solomon, E. 1991. Characterization of a zinc finger gene disrupted by the $\mathrm{t}(15 ; 17)$ in acute promyelocytic leukemia. Science 254: 1371-1374.

Goldstein, S., Moerman, E.J., Fujii, S., and Sobel, B.E. 1994. Overexpression of plasminogen activator inhibitor type-1 in senescent fibroblasts from normal subjects and those with Werner syndrome. J. Cell. Physiol. 161: 571-579.

Guldner, H.H., Szostecki, C., Grotzinger, T., and Will, H. 1992. IFN enhance expression of Sp100, an autoantigen in primary biliary cirrhosis. J. Immunol. 149: 4067-4073.

Gutch, M.J. and Reich, N.C. 1991. Repression of the interferon signal transduction pathway by the adenovirus E1A oncogene. Proc. Natl. Acad. Sci. 88: 7913-7917.

Hahn, W.C., Counter, C.M., Lundberg, A.S., Beijersbergen, R.L., Brooks, M.W., and Weinberg, R.A. 1999. Creation of human tumour cells with defined genetic elements. Nature 400: 464-468.

Hayflick, L. 1965. The limited in vitro lifetime of human diploid cell strains. Exp. Cell Res. 37: 614-636.

Jiang, W.Q. and Ringertz, N. 1997. Altered distribution of the promyelocytic leukemia-associated protein is associated with cellular senescence. Cell. Growth Differ. 8: 513-522.

Kakizuka, A., Miller, W.H.J., Umesono, K., Warrell, R.P.J., Frankel, S.R., Murty, V.V., Dmitrovsky, E., and Evans, R.M. 1991. Chromosomal translocation $\mathrm{t}(15 ; 17)$ in human acute promyelocytic leukemia fuses RAR alpha with a novel putative transcription factor, PML. Cell 66: 663-674.

Kamijo, T., Zindy, F., Roussel, M.F., Quelle, D.E., Downing, J.R., Ashmun, R.A., Grosveld, G., and Sherr, C.J. 1997. Tumor suppression at the mouse INK4a locus mediated by the alternative reading frame product p19ARF. Cell 91: 649-659. 
Kastner, P., Perez, A., Lutz, Y., Rochette-Egly, C., Gaub, M.P., Durand, B., Lanotte, M., Berger, R., and Chambon, P. 1992. Structure, localization and transcriptional properties of two classes of retinoic acid receptor alpha fusion proteins in acute promyelocytic leukemia (APL): Structural similarities with a new family of oncoproteins. EMBO J. 11: 629-642.

Korioth, F., Gieffers, C., Maul, G.G., and Frey, J. 1995. Molecular characterization of NDP52, a novel protein of the nuclear domain 10, which is redistributed upon virus infection and interferon treatment. J. Cell. Biol. 130: 1-13.

Kumar, S., Vinci J.M., Millis, A.J., and Baglioni, C. 1993. Expression of interleukin-1 alpha and beta in early passage fibroblasts from aging individuals. Exp. Gerontol. 28: 505513.

Lain, S., Midgley, C., Sparks, A., Lane, E.B., and Lane, D.P. 1999. An inhibitor of nuclear export activates the p53 response and induces the localization of HDM2 and p53 to U1A-positive nuclear bodies associated with the PODs. Exp. Cell Res. 248: 457-472.

Lambert, P.F., Kashanchi, F., Radonovich, M.F., Shiekhattar, R., and Brady, J.N. 1998. Phosphorylation of p53 serine 15 increases interaction with CBP. J. Biol. Chem. 273: 3304833053.

LaMorte, V.J., Dyck, J.A., Ochs, R.L., and Evans, R.M. 1998. Localization of nascent RNA and CREB binding protein with the PML-containing nuclear body. Proc. Natl. Acad. Sci. 95: 4991-4996.

Lavau, C., Marchio, A., Fagioli, M., Jansen, J., Falini, B., Lebon, P., Grosveld, F., Pandolfi, P.P., Pelicci, P.G., and Dejean, A. 1995. The acute promyelocytic leukaemia-associated PML gene is induced by interferon. Oncogene 11: 871-876.

Lill, N.L., Grossman, S.R., Ginsberg, D., DeCaprio, J., and Livingston, D.M. 1997. Binding and modulation of p53 by p300/ CBP coactivators. Nature 387: 823-827.

Lin, A.W., Barradas, M., Stone, J.C., van Aelst, L., Serrano, M., and Lowe, S.W. 1998. Premature senescence involving p53 and $\mathrm{p} 16$ is activated in response to constitutive MEK/MAPK mitogenic signaling. Genes \& Dev. 12: 3008-3019.

Linke, S.P., Clarkin, K.C., and Wahl, G.M. 1997. p53 mediates permanent arrest over multiple cell cycles in response to gamma-irradiation. Cancer Res. 57: 1171-1179.

Lowe, S.W., Ruley, H.E., Jacks, T., and Housman, D.E. 1993. p53-dependent apoptosis modulates the cytotoxicity of anticancer agents. Cell 74: 957-967.

Malumbres, M., Perez De Castro, I., Hernandez, M.I., Jimenez, M., Corral, T., and Pellicer, A. 2000. Cellular response to oncogenic ras involves induction of the Cdk4 and Cdk6 inhibitor p15(INK4b). Mol. Cell. Biol. 20: 2915-2925.

McConnell, B.B., Starborg, M., Brookes, S., and Peters, G. 1998. Inhibitors of cyclin-dependent kinases induce features of replicative senescence in early passage human diploid fibroblasts. Curr. Biol. 8: 351-354.

McCurrach, M.E., Connor, T.M., Knudson, C.M., Korsmeyer, S.J., and Lowe, S.W. 1997. bax-deficiency promotes drug resistance and oncogenic transformation by attenuating p53dependent apoptosis. Proc. Natl. Acad. Sci. 94: 2345-2349.

Melnick, A. and Licht, J.D. 1999. Deconstructing a disease: RAR $\alpha$, its fusion partners, and their roles in the pathogenesis of acute promyelocytic leukemia. Blood 93: 3167-3215.

Millis, A.J., Hoyle, M., McCue, H.M., and Martini, H. 1992. Differential expression of metalloproteinase and tissue inhibitor of metalloproteinase genes in aged human fibroblasts. Exp. Cell Res. 201: 373-379.

Morales, C.P., Holt, S.E., Ouellette, M., Kaur, K.J., Yan, Y., Wilson, K.S., White, M.A., Wright, W.E., and Shay, J.W. 1999. Absence of cancer-associated changes in human fibroblasts immortalized with telomerase. Nat. Genet. 21: 115-118.

$\mathrm{Mu}$, Z.M., Chin, K.V., Liu, J.H., Lozano, G., and Chang, K.S. 1994. PML, a growth suppressor disrupted in acute promyelocytic leukemia. Mol. Cell. Biol. 14: 6858-6867.

$\mathrm{Mu}$, X.C. and Higgins, P.J. 1995. Differential growth state-dependent regulation of plasminogen activator inhibitor type- 1 expression in senescent IMR-90 human diploid fibroblasts. J. Cell. Physiol. 165: 647-657.

Noda, A., Ning, Y., Venable, S.F., Pereira-Smith, O.M., and Smith, J.R. 1994. Cloning of senescent cell-derived inhibitors of DNA synthesis using an expression screen. Exp. Cell Res. 211: 90-98.

Nozawa, H., Oda, E., Nakao, K., Ishihara, M., Ueda, S., Yokochi, T., Ogasawara, K., Nakatsuru, Y., Shimizu, S., Ohira, Y., et al. 1999. Loss of transcription factor IRF-1 affects tumor susceptibility in mice carrying the Ha-ras transgene or nullizygosity for p53. Genes \& Dev. 13: 1240-1245.

Palmero, I., Pantoja, C., and Serrano, M. 1998. p19ARF links the tumour suppressor p53 to Ras. Nature 395: 125-126.

Prives, C. 1998. Signaling to p53: breaking the MDM2-p53 circuit. Cell 95: 5-8.

Samuelson, A.V. and Lowe, S.W. 1997. Selective induction of p53 and chemosensitivity in RB-deficient cells by E1A mutants unable to bind the RB-related proteins. Proc. Natl. Acad. Sci. 94: 12094-12099.

Serrano, M. 1997. The tumor suppressor protein p16INK4a. Exp. Cell Res. 237: 7-13.

Serrano, M., Lin, A.W., McCurrach, M.E., Beach, D., and Lowe, S.W. 1997. Oncogenic ras provokes premature cell senescence associated with accumulation of p53 and p16INK4a. Cell 88: 593-602.

Shelton, D.N., Chang, E., Whittier, P.S., Choi, D., and Funk, W.D. 1999. Microarray analysis of replicative senescence. Curr. Biol. 9: 939-945.

Sherr, C.J. and Weber, J.D. 2000. The ARF/p53 pathway. Curr. Opin. Genet. Dev. 10: 94-99.

Shieh, S.Y., Ikeda, M., Taya, Y., and Prives, C. 1997. DNA damage-induced phosphorylation of p53 alleviates inhibition by MDM2. Cell 91: 325-334.

Siliciano, J.D., Canman, C.E., Taya, Y., Sakaguchi, K., Appella, E., and Kastan, M.B. 1997. DNA damage induces phosphorylation of the amino terminus of p53. Genes \& Dev. 11: 34713481.

Sistonen, L., Holtta, E., Makela, T.P., Keski-Oja, J., and Alitalo, K. 1989. The cellular response to induction of the $\mathrm{p} 21 \mathrm{c}-\mathrm{Ha}-$ ras oncoprotein includes stimulation of jun gene expression. EMBO T. 8: 815-822.

Stadler, M., Chelbi-Alix, M.K., Koken, M.H., Venturini, L., Lee, C., Saib, A., Quignon, F., Pelicano, L., Guillemin, M.C., Schindler, C., et al. 1995. Transcriptional induction of the PML growth suppressor gene by interferons is mediated through an ISRE and a GAS element. Oncogene 11: 25652573.

Stott, F.J., Bates, S., James, M.C., McConnell, B.B., Starborg, M., Brookes, S., Palmero, I., Ryan, K., Hara, E., Vousden, K.H., et al. 1998. The alternative product from the human CDKN2A locus, p14(ARF), participates in a regulatory feedback loop with p53 and MDM2. EMBO J. 17: 5001-5014.

Sugrue, M.M., Shin, D.Y., Lee, S.W., and Aaronson, S.A. 1997. Wild-type p53 triggers a rapid senescence program in human tumor cells lacking functional p53. Proc. Nat1. Acad. Sci. 94: 9648-9653.

Tanaka, N., Ishihara, M., Kitagawa, M., Harada, H., Kimura, T., Matsuyama, T., Lamphier, M.S., Aizawa, S., Mak, T.W., and Taniguchi, T. 1994. Cellular commitment to oncogene-induced transformation or apoptosis is dependent on the tran- 
scription factor IRF-1. Cell 77: 829-839.

Uhrbom, L., Nister, M., and Westermark, B. 1997. Induction of senescence in human malignant glioma cells by p16INK4a. Oncogene 15: 505-514.

Vigo, E., Muller, H., Prosperini, E., Hateboer, G., Cartwright, P., Moroni, M.C., and Helin, K. 1999. CDC25A phosphatase is a target of E2F and is required for efficient E2F-induced $\mathrm{S}$ phase. Mol. Cell. Biol. 19: 6379-6395.

Vogt, M., Haggblom, C., Yeargin, J., Christiansen-Weber, T., and Haas, M. 1998. Independent induction of senescence by p16INK4a and p21CIP1 in spontaneously immortalized human fibroblasts. Cell Growth Differ. 9: 1923-1930.

Wang, Y., Blandino, G., Oren, M., and Givol, D. 1998a. Induced p53 expression in lung cancer cell line promotes cell senescence and differentially modifies the cytotoxicity of anticancer drugs. Oncogene 17: 1923-1930.

Wang, Z.G., Delva, L., Gaboli, M., Rivi, R., Giorgio, M., CordonCardo, C., Grosveld, F., and Pandolfi, P.P. 1998b. Role of PML in cell growth and the retinoic acid pathway. Science 279: 1547-1551.

Webley, K., Bond, J.A., Jones, C.J., Blaydes, J.P., Craig, A., Hupp, T., and Wynford-Thomas, D. 2000. Posttranslational modifications of p53 in replicative senescence overlapping but distinct from those induced by DNA damage. Mol. Cell. Biol. 20: 2803-2808.

Weis, K., Rambaud, S., Lavau, C., Jansen, J., Carvalho, T., Carmo-Fonseca, M., Lamond, A., and Dejean, A. 1994. Retinoic acid regulates aberrant nuclear localization of PMLRAR alpha in acute promyelocytic leukemia cells. Cell 76: 345-356.

Whyte, P., Buchkovich, K.J., Horowitz, J.M., Friend, S.H., Raybuck, M., Weinberg, R.A., and Harlow, E. 1988. Association between an oncogene and an anti-oncogene: The adenovirus E1A proteins bind to the retinoblastoma gene product. $\mathrm{Na}$ ture 334: 124-129.

Wong, G.H. and Goeddel, D.V. 1994. One-day northern blotting for detection of mRNA: NDGA inhibits the induction of MnSOD mRNA by agonists of type 1 TNF receptor. Methods Enzymol. 234: 244-252.

Yang, X., He, Z., Xin, B., and Cao, L. 2000. LMP1 of Epstein-Barr virus suppresses cellular senescence associated with the inhibition of p16INK4a expression. Oncogene 19: 2002-2013.

Zhong, S., Salomoni, P., and Pandolfi, P.P. 2000. The transcriptional role of PML and the nuclear body. Nat. Cell Biol. 2: E85-E90.

Zhu, J., Woods, D., McMahon, M., and Bishop, J.M. 1998. Senescence of human fibroblasts induced by oncogenic Raf. Genes \& Dev. 12: 2997-3007. 


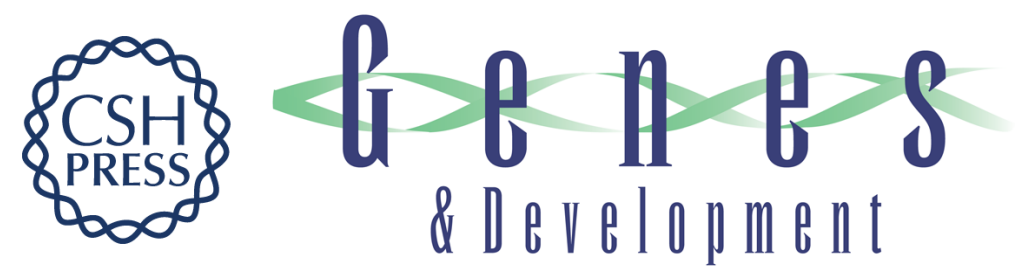

\section{PML is induced by oncogenic ras and promotes premature senescence}

Gerardo Ferbeyre, Elisa de Stanchina, Emmanuelle Querido, et al.

Genes Dev. 2000, 14:

Access the most recent version at doi:10.1101/gad.14.16.2015

References

This article cites 71 articles, 32 of which can be accessed free at: http://genesdev.cshlp.org/content/14/16/2015.full.html\#ref-list-1

\section{License}

Email Alerting

Receive free email alerts when new articles cite this article - sign up in the box at the top Service right corner of the article or click here.

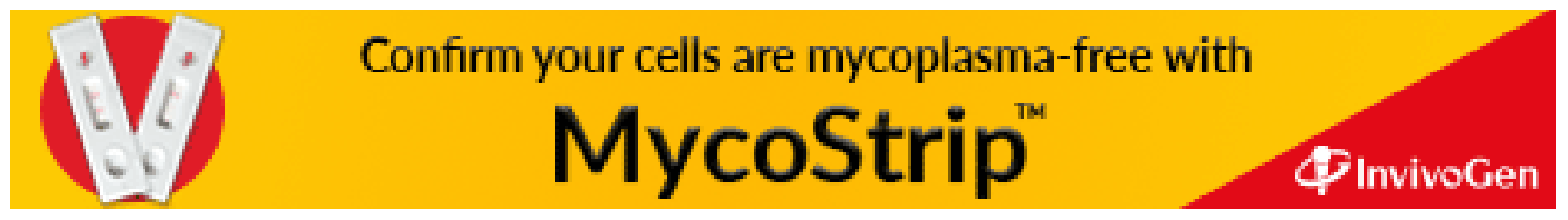

